Department of Botany. Of these about 1,900 are vascular cryptogams. The collection is rich in duplicates and there are about 20,000 specimens in all. Mr. Alston represented the Museum at the first South American Botanical Assembly at Rio de Janeiro last October, and later made an expedition across the north western corner of the South American continent from La Guayra in Venezuela to Bartacoas in southern Colombia, near the frontier of Ecuador. $\mathrm{He}$ studied the phytogeography of the area and collected specimens of the plants found.

\section{Anthropology and Ethnology in Switzerland}

Tize Bulletin der Schweizcrischen Gesellschaft für Anthropologie und Ethnologie, 1938-39, in addition to the annual report, obituary and other affairs of domestic concern, contains matter of wider interest for anthropologists in a contribution by the editor, Dr. O. Schlaginhaufen, "Untersuchungen über die Gesichtsform der Schweizer" which was presented to the International Congress of Anthropological and Ethnological Sciences at Copenhagen in August last, and summaries of the anthropological communications to the annual meeting of the Société Helvétique des Sciences Naturelles at Coire, August 28, 1938, from the Actes of that Society. Among these, a group of papers by Prof. E. Pittard deals comparatively with various lesser known physical characters of the Bushman and other peoples of South Africa, upon which the author's promised further interpretations will be awaited with considerable interest.

STUDExTs of the skeletal remains of man may bo directed particularly to the study by Dr. Albert L. Périer of a remarkable postmortem deformation of the mandible in six out of a collection of twelve Griqua skulls. In these six specimens, the bicondylar diameter of the mandible is by so far less than the corresponding basio-cranial diameter that it is impossible to articulate the jaw to the skull; and indeed, if it were not for the correspondence of other characters, it would be difficult to believo that their attribution to these crania is correct. In three of the skulls the discrepancy in diameter is ten millimetres or more. It is to be noted that the bone of the jaw is exceptionally thick, and the shrinkage absolutely symmetrical. No aćceptable explanation of the change presents itself, especially as no other example is found in one hundred and fifty South African skulls in the collection to which the Griqua skulls belong. The author points the moral that caution must bo exercised in drawing conclusions from isolated specimens in human palæontology.

\section{Tests of Materials}

NUMBERS 726 and 727 of Hermann's "Actualités scientifique et industrielle" (Paris) deal with tests of materials and aro entitled "La Structure et la Déformation des Solides" and "Essais des Métaux", respectively, the former of fifty pages (18 francs), the latter of seventy pages (25 francs), both well illus. trated. They are written by M. R. L'Hermite, assistant director of the Laboratory for Buildings and Public Works, Paris, and represent his lectures delivered at the Laboratory in 1937 and 1938. He emphasizes the influence of the fino structure of materials on their elastic properties and devotes half the first volumo to microscopic and $\mathrm{X}$-ray methods and their results. In the section on the deformations produced by applied forces he makes use of the Mohr-Caquot diagrams and theory, and ascribes deviations of experimental results from the theory to want of isotropy. In the second rolume many of the newer forms of machines for testing metals under tension, compression, shear, bending and shock aro described, as well as methods of testing hardness, wear and fatigue. The principal results obtained are given and are related to the Nohr theory.

\section{Bibliography of Seismology}

Turs bibliography, by E. A. Hodgson, published by the Dominion Observatory, Ottawa, for the period October-December 1938 has just been received. It contains 120 items from fourteen collaborators residing in eight countries, and it is noticeable that the United States and Holland are well represented and that Spain has a collaborator. Italy, the Balkan States, the U.S.S.R. and South America are this time not represented although it is known that soismological work is being done in all these places. One of the more recently studied branches of the subject is well illustrated by a paper by A. Belluigi ("Seismisch-electrischo Wirkungen und neu mögliche seismische Anwendungen", Bei. Angew. Geoph., 7, Heft 3, 260-264, bib., Leipzig, 1938). It concerns the new seismic-electric effect pointed out by American authors, and the author suggests that its probablo causo consists in electrochemical alterations produced by elastic waves as Thyssen, Hummel and Rülke have demonstrated. It is further suggested that now electro-elastic seismometers be planned, as these should afford advantages over the present seismometers in exactness of reproduction of impulses, owing to the absence of inertia masses, and they should measure at the same time the electrical resistivity. Following the bibliography is a very valuable double index for the whole year, arranged first by subjects and then by names.

\section{Journal of the Royal Agricultural Society}

Tre Journal of the Royal Agricultural Society of England has reached its hundredth volume, and with this issue certain changes of format are being made. In place of the single annual volume, a periodical appearing three times a year is to be published. The first part, issued in June, consists mainly of the usual reviews of agricultural research under the familiar title, "The Farmer's Guide", but also includes the annual financial statement. Part 2 will appear in November and will contain a number of contributed articles and the various reports on the Show. Part 3 will be published in March and will also contain a number of contributed articles, the report of the Council to the annual general meeting, the annual reviews of agricultural law and agricultural statistics, 
and the annual report of the Society's scientific officers and of its research committee. Each part will include a summary of the proceedings of the Council at its meetings in the previous two or three months and will be separately indexed. The June issue for 1939 (100, Part 1$)$ is now available and can be obtained from the Society, 16 -Bedford Square, W.C.1, prico $5 s$.

\section{The Grid System}

THE Association of Engineering and Shipbuilding Draughtsmen publishes (Draughtsman Publishing Co., Ltd., 96 St. Georgo's Square, London, S.W.I) a series of pamphlets containing much useful information. A recent issue, entitled "The Grid System", contains a historical survey of electricity supply in Great Britain from the formation of the Fdison Light Co. in London in 1881, through the troublous years when various Acts of Parliament were passed which in some cases hampered the industry; the first contracts for the 'grid-iron' or grid system were placed in the year 1928, and this was followed by the growth in the space of six years of 4,000 miles of transmission lines and the placing of 26,000 steel pylons. The advantages of standardizing frequency are discussed and the systems adopted for grid tariffs and trading. Much of the information is not readily obtainable elsewhere. A list is included of A.E.S.D. printed pamphlets and other publications written specially for engineering and shipbuilding draughts. men.

\section{Dutch Colonial Institute}

TuE "Acht en Twintigste Jaarverslag van het Koloniaal Instituut" gives a brief account of the work of the Dutch Colonial Institute at Amsterdam during the year 1938. Its activities have included public lectures, courses of instruction in tropical hygiene, researches on tropical diseases such as yellow fever and psittacosis, studies in mosquito control and the chemical examination of more than four thousand samples. The valuable work recorded in this year-book gives ample evidence that the Dutch Colonial Institute continues actively to servo the interests of Holland and its oversea possessions.

\section{The Scientific Films Committee}

ABout two years ago the Association of Scientific Workers set up a Scientific Films Committee, to act as a clearing-house of information on scientific films. During this time it has seen and appraised some 150 films, and has produced a graded list of these films with particulars of length, availability, subject-matter, distributor, etc. This list is available to anyone interested at a cost of $1 s$. If desired, the Committee will undertake, for a small charge, to choose a programme to suit any particular requirements. In addition, the Committee has compiled an index of scientific and film experts willing to be put in touch with people requiring advice on the making of films. Full particulars of the services offered can be obtained from the Secretary, Scientific Films Committee, 30 Bedford Row, London, W.C.1.

\section{Apparatus for the Physical Laboratory}

Tre twenty-fifth edition of the catalogue of physical laboratory apparatus and equipment recently issued by Messrs. W. and J. George, Ltd., proprietors of F. E. Becker and Co., London and Birmingham, is an impressive volume of 824 pages. The contents cover the whole of the equipment needed for the teaching of physics in all types of educational institution from elementary school to university. For convenience of reference, the catalogue is classified into thirteen sections within which the items are arranged in the usual text-book order of treatment of the subject. Physics is divided into ten sections. Tho remaining three deal with laboratory fittings, equipment and materials, with lantorn slides, ciné films and with text-books. Out-of-date items have been entirely replaced by new apparatus, and the designs of many standard instruments have been improved. In addition to the well-known series of Nivoc products made by Messrs. Georgo, other British and foreign items are included so that every normal requirement in physies teaching is to be found within the covers. But it is more than a mere catalogue. Each item dealing with less well-known apparatus has a brief description of the method of use, together with the necessary theory, supplemented in some of the entries by typical numerical results obtained with the apparatus in the laboratory. Some of theso descriptions cover a page or two. The specially drawn illustrations are very clear and project well in the epidiascope. Altogether the catalogue, with its detailed index, corner page headings and numerous cross-references, makes a noteworthy addition to the library of any educational or industrial physics laboratory.

\section{Book Reviews}

SIDE by side with the increase in numbers of scientific papers which has been referred to repeatedly in this journal in recent years, there has been a steady if smaller growth of scientific and technical text-books, monographs and other books of interest to readers of NATURE, and the task of presenting to the scientific reader a reasoned survey of such literature has become increasingly difficult in the limited space available. Following the customary practice, longer notices of books have been printed under appropriate titles, while shorter notices have been brought together without a special heading; in addition, a classified list of recent scientific and technical books, whether received for notice in NAture or not, is printed every month as a supplement to the journal. In the present issue, the shorter notices, which used to appear in the body of the journal immediately after the longer reviews, have been placed in the supplement with the books list. By publishing these shorter notices once a month in this way, it is possible to arrange them according to subject and it is also hoped to increase the total amount of space given to such notices. For the convenience of those who wish to bring the books lists together when binding up a volume, the list 